Original Research Paper

\title{
Field Evaluation of Sugarcane Orange Rust for First Clonal Stage of the CP Cultivar Development Program
}

\author{
${ }^{1}$ Duli Zhao, ${ }^{2}$ R. Wayne Davidson, ${ }^{2}$ Miguel Baltazar and ${ }^{1}$ Jack C. Comstock \\ ${ }^{1}$ USDA-ARS, Sugarcane Field Station, Canal Point, Florida, USA \\ ${ }^{2}$ Florida Sugar Cane League, Inc., Clewiston, Florida, USA
}

Article history

Received: 12-12-2014

Revised: 25-12-2014

Accepted: 27-1-2015

Corresponding Author: Duli Zhao

USDA-ARS, Sugarcane Field Station, Canal Point, Florida, USA

Tel: 011-1-561-924-5227

Fax: 011-1-561-924-6109

Email: duli.zhao@ars.usda.gov

\begin{abstract}
Consistent development of high-yielding sugarcane (a complex hybrid of Saccharum spp.) cultivars with resistance or tolerance to biotic and abiotic stresses is critical to commercial sugarcane production. Currently, orange rust (caused by Puccinia kuehnii E.J. Butler) is a big challenge for the sugarcane production in Florida, USA. A better understanding of sugarcane genotypic variability in response to orange rust disease will help optimize breeding and selection strategies for disease resistance. Orange rust ratings, scaled from non-infection (0) to severe infection (4) with intervals of 0.5 , were recorded from genotypes at the first clonal selection stage (Stage I) of the Canal Point sugarcane breeding and cultivar development program in Florida. Data were collected from all 14,272 and 12,661 genotypes and four replicated reference cultivars, CP 78-1628, CP 80-1743, CP 88-1762 and CP 89-2143, in July-August 2012 and 2013, respectively. Mean rust rating, \% of rust infection and rust severity in each family (i.e., progeny of the cross from a female and male) and female parent and their Coefficients of Variation (CV) within and among families (females) were estimated. Results indicated that considerable variation exists in rust tolerance among families or females. The families or females for their progenies with the high susceptibility or resistance to orange rust were identified and ranked. The findings of this study are useful for evaluating sugarcane crosses and parents for rust disease and can help breeders use desirable parents for crossing and improve genotypic resistance to orange rust in the sugarcane breeding programs.
\end{abstract}

Keywords: Sugarcane, Canal Point (CP) Sugarcane Breeding and Cultivar Development Program, Orange Rust, Genotype/Parental Evaluation for Rust Resistance

\section{Introduction}

Sugarcane (a complex hybrid of Saccharum spp.) is an important industrial crop in Florida, USA with an annual economic impact of more than $\$ 677$ million (USDA-NASS, 2014). Consistent and continuous development of high-yielding sugarcane cultivars with resistance or tolerance to biotic and abiotic stresses is critical for commercial sugarcane production in South Florida (Zhao et al., 2010). The USDA-ARS Sugarcane Field Station at Canal Point $\left(26.52^{\circ} \mathrm{N} ; 80.36^{\circ} \mathrm{W}\right)$, Florida was initially established at its present site in 1920 to conduct sugarcane breeding and selection for Louisiana to make crosses and produce true sugarcane seed for the sugarcane industry. Since the 1960s, the Canal Point station has been developing sugarcane cultivars with $\mathrm{CP}$ prefixes for Florida under a three-party cooperative agreement among the USDA-ARS, the University of Florida and the Florida Sugar Cane League, Inc. Also, the Canal Point station still makes crosses for the USDA-ARS in Houma, Louisiana. The CP cultivars now account for more than $90 \%$ of the hectarage in Florida up from $14 \%$ in 1970. In 2012, the top six major sugarcane cultivars grown in Florida were 'CP 89-2143' (Glaz et al., 2000), 'CP 881762' (Tai et al., 1997), 'CP 00-1101' (Gilbert et al., 2008), 'CP 96-1252' (Edme and Tai et al., 2005), 'CL 88-4730' (a cultivar of the United States Sugar Corporation) and 'CP 78-1628' (Tai et al., 1991) and their percent hectares were $20.7,19.2,10.2,8.6,7.4$ and $7.3 \%$, respectively (Rice et al., 2013).

The Canal Point sugarcane breeding and cultivar development program (CP program) consists of six stages, namely Crossing, Seedlings and Stages I, II, III and IV (Zhao et al., 2012). It takes at least eight years to 
release a cultivar from the time a cross is made (Tai and Miller, 1989). Cane yield ( $\mathrm{TCH}, \mathrm{Mg} \mathrm{ha}^{-1}$ ), commercial recoverable sucrose (CRS, $\mathrm{kg}$ sucrose $\mathrm{Mg}^{-1}$ cane) and sucrose yield ( $\mathrm{TSH}, \mathrm{Mg} \mathrm{ha}^{-1}$ ) with disease resistance are the major agronomic traits considered in advancing sugarcane clones during the selection stages. Edme and Miller et al. (2005) reported that CRS, TCH and TSH of Florida commercial sugarcane cultivars linearly increased by $26.0,15.5$ and $47.0 \%$, respectively, from 1968 to 2000 . Underscoring the critical need for cultivar development for the Florida sugarcane industry, about $69 \%$ of the sugar yield gain in Florida came from genetic improvement attributable to the CP program (Edme and Miller et al., 2005), indicating importance of the CP program in sugarcane production in Florida.

Sugarcane orange rust, caused by $P$. kuehnii (W. Krüger) E.J. Butler, resulted in considerable economic loss in Australia (Braithwaite et al., 2009). This disease was recorded in Florida for the first time in 2007 (Comstock et al., 2008). Sugarcane orange rust has caused significant yield losses in Florida because most widely planted commercial cultivars in the region are susceptible to this disease (Raid et al., 2013). Orange rust has also been found in sugarcane growing in the Central American countries of Guatemala (Ovalle et al., 2008), Costa Rica (Chavarría et al., 2009), Nicaragua (Chavarría et al., 2009), Mexico (Flores et al., 2009), El Salvador (Flores et al., 2009), Panama (Flores et al., 2009) and more recently in Brazil (Barbasso et al., 2010) and in Louisiana, USA (Grisham et al., 2013). Zhao et al. (2011) determined physiological mechanisms of the orange rustinduced reductions in sugarcane growth and yield by quantifying effects of this disease on leaf relative chlorophyll level, photosynthetic rate, dark respiration rate, photosynthetic radiation use efficiency, carbon use efficiency and the relationships between these leaf photosynthetic components and rust disease ratings.

Currently, leaf orange rust and brown rust (caused by Puccinia melanocephala H. \& P. Sydow) diseases are great challenges for sugarcane production in Florida. Most dominant commercial cultivars in Florida are susceptible to one or both rusts. Growers use fungicides to control the negative effects of rusts on yields, but the cost of three split applications of fungicides (at a hectarage level) during a growing season is equivalent to 3 tonns of cane yield lost per hectare. The frequent applications of fungicides and low net profits preclude their use for controlling sugarcane brown rust (Jiang, 1985) and orange rust (Staier et al., 2003), making cultivar resistance and cultural practices are the most viable alternatives. Therefore, development of rust resistant varieties is the first priority for sustaining sugarcane production in Florida. Scientists in the $\mathrm{CP}$ program and in industry are using multiple approaches to develop new cultivars with rust resistance and high yields. Cultivars developed in the CP program not only are used in the United States, but also many Central American sugarcane industries use them for either breeding or commercial production (Machado, 2013). Therefore, evaluation and screening of genotypes for resistance to rusts in the $\mathrm{CP}$ program are critical for sustainable sugarcane production in USA and other countries. Although Sood et al. (2009) developed a whorl inoculation method to more accurately and efficiently test sugarcane genotype resistance in brown rust (Sood et al., 2009) and orange rust (Zhao et al., 2011), it is still difficult to use the artificial inoculation test in Stage I of the CP program because of a large number $(12,000-15,000)$ of genotypes in this stage due to limited resources (Zhao et al., 2012). Therefore, natural infection has been the primary means of assessing rust resistance in the Stage-I sugarcanes in the CP program.

The selection of which sugarcane clones to be used as crossing parents is a crucial decision for breeders. Knowledge and better understanding of variability in rust infection and severity among genotypes may provide useful information for genotype advancement and for efficient use of parents in future crossing efforts for developing orange rust resistance. Thus, a study was conducted in the Stage I fields of the CP program at the USDA-ARS Sugarcane Field Station, Canal Point, Florida. Objectives of this study were to determine variability in orange rust ratings among crosses based on data collected from the Stage I clones of the CP program in 2012 and 2013 and to use the information for consideration of parental selection and cross appraisal. Overall, orange rust in the 2012 and 2013 sugarcane growing seasons in south Florida were the most severe in the last five years due to favorable environment conditions for rust development. The data of orange ratings in Stage I may be useful for achieving the specific breeding objectives for rust resistance.

\section{Materials and Methods}

\section{Plant Culture}

Individual stalks of 14,272 genotypes in 2012 and 12,661 genotypes in 2013 were visually selected from fields of the 2011 and 2012 Seedling stages and planted in single-row plots in the Stage I fields of the CP program in January of 2012 and 2013, respectively. All the visually selected genotypes in the Seedling stages did not show clear orange rust disease symptoms due to late transplanting (Mid May) in the CP program. To facilitate stalk transport and planting, two to five stalks (each stalk came from a true seed plant) in the Seedling fields were bundled and labeled by family (i.e., cross) prior to advancing them to Stage I (Zhao et al., 2012). These bundles were randomly distributed in the Stage I fields. One stalk was placed in each plot and cut into two sections (each approximately $0.9 \mathrm{~m}$ long). The two sections were placed in the center of the plot as double pieces of seedcane. The plot length was $2.4 \mathrm{~m}$, with 1.5 $\mathrm{m}$ between-row spacing. There was a $1.5-\mathrm{m}$ gap between adjacent clones within a row to allow scientists to 
recognize individual clones during disease rating, growth vigor evaluation and selection and to easily distinguish individuals at selection time. Four commercial cultivars, $\mathrm{CP}$ 78-1628, CP 80-1743 (Deren et al., 1991), CP 88-1762 and CP 89-2143, were used as checks each year and one check plot was randomly planted in approximately every 100 plots. There were approximately 40 replicated plots for each check cultivar each year. There was a $4.5 \mathrm{~m}$ alley every eight rows to facilitate field maintenance and genotype selection.

\section{Evaluation of Orange Rust}

During the grand growth (July-August) in 2012 and 2013 , orange rust ratings were recorded in all plots of Stage I under natural infection using a scale from 0 (no rust infection) to 4 (most severe rust infection) with intervals of 0.5 . The 0 to 4 scale levels were defined as: $0=$ no rust, $1=$ one to a few pustules, $2=$ patching presented, 3 = patching widespread up into the upper canopy with some lower leaf death and $4=$ massive amounts of rust pustules with heavy lower leaf death. In general, the plants with rust ratings of 0 to 1 were considered resistant or tolerant, with rating of 2 were considered moderately susceptible and with ratings of 3 and 4 were considered susceptible and highly susceptible.

Additionally, all clones were visually evaluated for other diseases [brown rust, leaf scald (Xanthomonas albilineans), smut (Sporisorium scitamineum) and mosaic] and plant vigor and agronomic traits (Zhao et al., 2012) at the same time and in early September. A subjective plant vigor rating was determined for individual clones using a scale from 1 (worst) to 9 (best). All clones with a vigor rating $\geq 6$ or better than that of check cultivars, acceptable rust resistance (rust rating $\leq 1$ ) and no other disease symptoms were further assessed for Brix (an indicator of sucrose content) in early November. Approximately 1,500 best clones with the largest vigor $\times$ Brix products and proper disease resistance were advanced to Stage II. Recently, Zhao et al. (2012) reported the details of vigor rating, Brix and the Stage-I selection strategies in the CP program. Therefore, we mainly focused on orange rust on the basis of families and female parents in this study. Three variables of mean orange rust rating, percent of rust infection and rust severity were used to determine variation of rust diseases among families or females based on their progenies. These variables were defined and estimated using the following formulas:

Mean orange rust rating $=\Sigma$ (rust rating $) \div$ total number of clones (including clones with 0 rating)

Percent of infection $=($ the number of clones infected $\div$ total number of clones $) \times 100$

Severity $=\Sigma$ (rust rating) $\div$ the number of clones infected

\section{Data Analysis}

For the four check cultivars, replicated plots were completely randomized in the Stage-I field both years. The MIXED procedure of SAS (SAS Institute Inc., Cary, NC) was used to test differences of cultivar, year and their interaction for the mean rating of orange rust and for rust severity. If the hypothesis of equal means between the check cultivars was rejected by the $F$ test, the trait means were separated with the LSD at $P=0.05$. The LSD values were calculated with the SE values generated by the Diff option in the SAS MIXED procedure.

For the Stage I clones, their parental combinations in the Crossing stage varied annually. Thus, the Stage I data were analyzed separately for each year. Orange rust distributions were determined by pooling data across all clones within a year. Data of orange rust were analyzed for each family and female parent. Data of male parents were not analyzed because many of the progeny in the 2012 and 2013 Stage I were developed from Poly crosses (i.e., where a female tassel received pollen from several different male tassels and their male parents could be any one of these males). Thus, the specific males were unknown for all the Poly crosses. For families and female parents that had $\geq 15$ progeny clones planted in Stage I, the mean ratings and Coefficients of Variation (CVs) were determined for orange rust to assess variability. The means and CVs were calculated using PROC MEANS of SAS. Then, the CVs of amongfamilies (females) were obtained based on their means and the CVs of within-families (-females) were estimated by averaged $\mathrm{CVs}$ of individual families (females). Coefficients of variation for the rust in each family were calculated from the individual clonal values of rust rating from all clones within a family or female according to Zhao et al. (2012). The within-family or within-female $\mathrm{CV}$ for each parameter was estimated by calculating the overall mean $\mathrm{CV}$ of all individual family (female) CVs for that trait. The among-family CVs were estimated using the mean (rather than individual clone) values of each family (female). For example, to calculate the among-family $\mathrm{CV}$ of 20 families for orange rust, we would have calculated the $\mathrm{CV}$ based on the standard deviation and overall mean from the 20 mean rust rating values of each of the 20 families. The variability amongand within-families was described using respective CVs. The top 20 families that were most susceptible or most tolerant to orange rust in each year were further determined based on ranking their mean rust ratings. The top 20 females in which their progenies were most susceptible or most tolerant to the rust in each year were also determined based on mean ratings of orange rust.

\section{Results}

\section{Orange Rusts of Check Cultivars}

There were significant differences among check cultivars and between years in mean ratings of orange 
rust and the cultivar $\times$ year interactions were also highly significant (Table 1). The mean rating of orange rust in 2012 was lower than that in 2013. Averaged across the four cultivars, mean ratings of orange rust in 2012 and 2013 were 1.0 and 2.0, respectively. CP 78-1628 had significantly lower mean rating of orange rust than other three cultivars in both years.

The differences in \% infection of orange rust among cultivars or between years were similar to those in the mean rust ratings. On the other hand, the differences in severity were relatively less among cultivars or between years compared with \% infection (Table 1). Orange rust severity differed significantly among cultivars, but did not differ between years. There was no interaction of cultivar $\times$ year on orange rust severity (Table 1 ). Averaged across years, the orange rust severity values of CP 78-1628, CP 80-1743, CP 88-1762 and CP 89-2143 were $1.8,2.3,2.2$ and 2.1 , respectively.

\section{Distributions of Orange Rust Ratings}

Numbers of clones used for orange rust ratings in Stage I of the CP program were 14,272 in 2012 and 12,661 in 2013 (Fig. 1). These did not include 158 and 166 replicated check plots in 2012 and 2013, respectively. The \% infections of orange rust in 2012 and 2013 were 18.3 and $50.2 \%$, respectively. The distributions of orange rust ratings based on the number of clones at each rating level are given in Fig. 1. Although the peak frequency of the rating distribution for orange rust was at 2 and the overall severity value was also approximately 2 in both years, the peak value of orange rust in 2012 was smaller than that in 2013 (Fig. 1). The CVs of orange rust ratings across the infected clones in $2012(2,607)$ and $2013(6,356)$ were 19.8 and $28.8 \%$, respectively. Additionally, the \% infection and mean rating of orange rust in 2013 were much greater than in 2012. The differences in severity between years were small (Fig. 1).

\section{Variability in Clonal Numbers and Rust Ratings among Families}

Total crosses (families) advanced to Stage I from the Seedling stage by individual selection were 576 and 455, respectively, in 2012 and 2013. Clone numbers among families ranged from 1 to 214 with a mean of 25 in 2012 and from 1 to 209 with a mean of 28 in 2013 and their CVs in two years were 113 and $100 \%$, respectively (Table 2).

Table 1. Mean rating, percent of infections and severity of orange rust of four check cultivars tested with sugarcane clones in the Stage I field of the Canal Point (CP) sugarcane cultivar development program in 2012 and 2013

\begin{tabular}{|c|c|c|c|c|}
\hline Cultivar & Clone \# & Mean rating & $\%$ infection & Severity \\
\hline \multicolumn{5}{|l|}{2012} \\
\hline CP 78-1628 & 40 & $0.13 \mathrm{~b}$ & 7.5 & 1.67 \\
\hline CP 80-1743 & 40 & $1.46 \mathrm{a}$ & 65.0 & 2.25 \\
\hline CP 88-1762 & 40 & $1.24 \mathrm{a}$ & 57.5 & 2.15 \\
\hline CP 89-2143 & 38 & $1.18 \mathrm{a}$ & 55.3 & 2.14 \\
\hline Mean & 40 & 1.00 & 46.3 & 2.05 \\
\hline \multicolumn{5}{|l|}{2013} \\
\hline CP 78-1628 & 40 & $1.69 \mathrm{~b}$ & 87.5 & 1.93 \\
\hline CP 80-1743 & 40 & $2.10 \mathrm{a}$ & 97.5 & 2.31 \\
\hline CP 88-1762 & 43 & $2.02 \mathrm{a}$ & 93.0 & 2.18 \\
\hline CP 89-2143 & 43 & $2.06 \mathrm{a}$ & 97.7 & 2.11 \\
\hline Mean & 42 & 1.97 & 93.9 & 2.13 \\
\hline Effect & DF & & $P>F$ & \\
\hline Cultivar & 3 & $<0.0001$ & --- & 0.0001 \\
\hline Year & 1 & $<0.0001$ & --- & 0.2451 \\
\hline $\mathrm{C} \times \mathrm{Y}$ & 3 & 0.0043 & --- & 0.4625 \\
\hline
\end{tabular}

Table 2. Maximum (Max), Minimum (Min), Mean, Standard Deviation (SD) and Coefficient of Variation (CV) for clone number and mean ratings of Orange Rust (OR) of 576 (in 2012) and 455 (in 2013) sugarcane families with a total of 14,272 and 12,661 clones, respectively, tested in the 2012 and 2013 Stage I fields in the Canal Point (CP) sugarcane cultivar development program

\begin{tabular}{|c|c|c|c|c|}
\hline \multirow[b]{2}{*}{ Parameter } & \multicolumn{2}{|l|}{2012} & \multicolumn{2}{|l|}{2013} \\
\hline & Clone (No. family ${ }^{-1}$ ) & OR rating & Clone (No. family ${ }^{-1}$ ) & OR rating \\
\hline Max & 214 & 2.50 & 209 & 2.50 \\
\hline Min & 1 & 0.00 & 1 & 0.00 \\
\hline Mean & 25 & 0.46 & 28 & 0.96 \\
\hline $\mathrm{SD}$ & 28 & 0.49 & 28 & 0.51 \\
\hline CV (\%, among families) & 113 & 104.90 & 100 & 52.70 \\
\hline CV (\%, within families) & --- & 184.20 & --- & 119.10 \\
\hline
\end{tabular}


Table 3. Number of total sugarcane clones planted, mean Orange Rust (OR) rating, \% of infection and severity and their parents for the 20 families with the highest mean OR ratings using 295 and 263 families with $\geq 15$ clones in Stage I of the Canal Point (CP) sugarcane cultivar development program in 2012 and 2013, respectively

2012

\begin{tabular}{|c|c|c|c|c|c|c|c|c|c|c|c|c|c|}
\hline \multirow[b]{2}{*}{ Family } & \multirow[b]{2}{*}{ No. clone } & \multirow[b]{2}{*}{ OR rating } & \multirow[b]{2}{*}{$\%$ infect } & \multirow[b]{2}{*}{ Severity } & \multicolumn{2}{|l|}{ Parent } & \multirow[b]{2}{*}{ Family } & \multirow[b]{2}{*}{ No. clone } & \multirow[b]{2}{*}{ OR rating } & \multirow[b]{2}{*}{$\%$ infect } & \multirow[b]{2}{*}{ Severity } & \multicolumn{2}{|l|}{ Parent } \\
\hline & & & & & Female & Male & & & & & & Female & Male \\
\hline $\mathrm{X} 4011 \mathrm{~A}$ & 26 & 2.23 & 88.5 & 2.52 & СР00-1101 & Ho05-961 & X08-0283 & 37 & 2.11 & 86.5 & 2.44 & СР04-1250 & CPCL97-0393 \\
\hline X09-1136 & 75 & 1.54 & 16.0 & 2.31 & СР94-2203 & Mix09G & X10-0176 & 16 & 2.09 & 100.0 & 2.09 & СР06-2897 & CL88-2747 \\
\hline X09-0109 & 37 & 1.51 & 24.3 & 2.33 & СР04-1250 & СР04-1844 & X10-0362 & 92 & 2.02 & 90.2 & 2.23 & СР94-2203 & СР88-1762 \\
\hline X09-0320 & 21 & 1.50 & 66.7 & 2.25 & CP04-1250 & Mix09A & X09-0783 & 40 & 1.99 & 90.0 & 2.21 & CP88-1762 & Poly09-21 \\
\hline X10-0353 & 16 & 1.50 & 68.8 & 2.18 & СР94-2203 & CP06-2042 & X10-0664 & 55 & 1.97 & 81.8 & 2.41 & CP94-2203 & СР97-1777 \\
\hline X09-0069 & 96 & 1.43 & 62.5 & 2.25 & CL87-1630 & СР04-1844 & X10-0089 & 43 & 1.97 & 83.7 & 2.35 & CL94-0150 & СР06-3025 \\
\hline X10-0546 & 18 & 1.33 & 61.1 & 2.18 & СР06-2335 & Poly10-11 & X09-1077 & 31 & 1.95 & 90.3 & 2.16 & CL89-5189 & СР94-2059 \\
\hline $\mathrm{X} 10-0360$ & 16 & 1.31 & 62.5 & 2.10 & CPCL06-3458 & CP88-1762 & X09-0793 & 20 & 1.95 & 90.0 & 2.17 & CL87-2282 & Poly09-21 \\
\hline X09-0793 & 49 & 1.30 & 59.2 & 2.19 & CL87-2882 & Poly09-21 & X10-0318 & 21 & 1.88 & 90.5 & 2.08 & СР07-1860 & СР97-1777 \\
\hline X09-1144 & 29 & 1.28 & 51.7 & 2.06 & CР99-1896 & Mix09G & X11-0471 & 21 & 1.81 & 85.7 & 2.11 & СР04-1844 & CPCL02-8021 \\
\hline X10-0269 & 31 & 1.24 & 58.1 & 2.14 & CPCL02-6848 & Poly10-05 & X10-0800 & 28 & 1.79 & 85.7 & 2.08 & CPCL97-1864 & CPCL01-6755 \\
\hline X09-1150 & 25 & 1.22 & 56.0 & 2.18 & СР05-1518 & CP88-1762 & X10-0895 & 28 & 1.77 & 89.3 & 1.98 & CPCL96-4974 & Poly10-19 \\
\hline X10-0535 & 23 & 1.22 & 52.2 & 2.33 & СР02-1554 & Poly10-10 & X09-0069 & 51 & 1.75 & 76.5 & 2.29 & CL87-1630 & СР04-1844 \\
\hline X08-1022 & 55 & 1.12 & 50.9 & 2.23 & СР04-1250 & СР04-2166 & X09-1136 & 28 & 1.75 & 85.7 & 2.04 & СР94-2203 & MaleMix09G \\
\hline X09-1034 & 34 & 1.10 & 50.0 & 2.21 & CPCL99-2103 & CL88-4730 & X09-0856 & 20 & 1.75 & 80.0 & 2.19 & CL89-5189 & Poly09-22 \\
\hline $\mathrm{X} 10-0273$ & 16 & 1.09 & 50.0 & 2.19 & ТСР97-4416 & Poly10-05 & X09-0893 & 18 & 1.75 & 83.3 & 2.10 & CP97-1387 & Poly09-24 \\
\hline X07-1302 & 18 & 1.08 & 50.0 & 2.17 & СР03-1401 & Mix07S & X10-0562 & 70 & 1.73 & 82.9 & 2.09 & СР94-2203 & Poly10-12 \\
\hline X09-0783 & 44 & 1.08 & 50.0 & 2.16 & СР88-1762 & Poly09-21 & X10-0940 & 31 & 1.73 & 80.6 & 2.14 & СР89-2377 & СР80-1743 \\
\hline X10-0540 & 17 & 1.00 & 41.2 & 2.43 & CP84-1198 & Poly10-10 & X09-1034 & 18 & 1.72 & 77.8 & 2.21 & CPCL99-2103 & CL88-4730 \\
\hline X09-0979 & 77 & 0.99 & 46.8 & 2.13 & СР99-1896 & Poly09-25 & X09-0796 & 16 & 1.69 & 81.3 & 2.08 & CL90-4500 & Poly09-21 \\
\hline Mean ${ }^{\dagger}$ & $36(42)$ & $1.30(0.39)$ & $68.8(35.8)$ & $2.23(2.0)$ & & & Mean & $34(43)$ & $1.86(0.97)$ & $85.6(51.6)$ & $2.17(1.85)$ & & \\
\hline Max & $96(214)$ & $2.23(2.23)$ & $82.1(82.1)$ & $2.52(3.0)$ & & & $\operatorname{Max}$ & $92(209)$ & $2.11(2.11)$ & $100(100)$ & $2.44(2.44)$ & & \\
\hline Min & $16(15)$ & $0.99(0.00)$ & $52.9(2.3)$ & $2.06(1.4)$ & & & Min & $16(15)$ & $1.69(0.11)$ & $76.5(5.3)$ & $1.98(1.00)$ & & \\
\hline $\mathrm{CV}(\mathrm{A})^{\ddagger}$ & $64.4(71)$ & $21.4(94.1)$ & $9.8(44.5)$ & $5.1(10.5)$ & & & $\mathrm{CV}(\mathrm{A})$ & $58(66)$ & $7.3(46.9)$ & $6.4(39.4)$ & $5.6(13.5)$ & & \\
\hline $\mathrm{CV}(\mathrm{W})$ & & $89.7(255)$ & & $15.5(13.8)$ & & & $\mathrm{CV}(\mathrm{W})$ & & $47.4(118.6)$ & & $21.3(27.3)$ & & \\
\hline
\end{tabular}

${ }^{\dagger}$ The first values of mean, Maximum (Max), Minimum (Min) and CV are calculated based on the top 20 families and the second values within parentheses are based on all 279 (2012) or 265 (2013) families with $\geq 15$ clones planted

${ }^{*}$ The CV (A) and CV (W) represent among- and within-family CVs, respectively

Table 4. Number of total sugarcane clones planted, mean Orange Rust (OR) rating, \% of infection and severity and their parents for the 20 families with the lowest mean OR ratings using 295 and 263 families with $\geq 15$ clones in Stage I of the Canal Point (CP) sugarcane cultivar development program in 2012 and 2013, respectively

2012

\begin{tabular}{|c|c|c|c|c|c|c|c|c|c|c|c|c|c|}
\hline & \\
\hline \multirow[b]{2}{*}{ Family } & \multirow[b]{2}{*}{ No. clone } & \multirow[b]{2}{*}{ OR rating } & \multirow[b]{2}{*}{$\%$ infect } & \multirow[b]{2}{*}{ Severity } & \multicolumn{2}{|l|}{ Parent } & \multirow[b]{2}{*}{ Family } & \multirow[b]{2}{*}{ No. clone } & \multirow[b]{2}{*}{ OR rating } & \multirow[b]{2}{*}{$\%$ infect } & \multirow[b]{2}{*}{ Severity } & \multicolumn{2}{|l|}{ Parent } \\
\hline & & & & & Female & Male & & & & & & Female & Male \\
\hline $\begin{array}{l}\mathrm{X} 09-0698 \\
\end{array}$ & 20 & 0.00 & 0 & 0 & CР06-3098 & CР92-1167 & X10-0382 & 63 & 0.32 & 20.6 & 1.54 & CPCL01-6755 & Poly10-09 \\
\hline X09-1242 & 24 & 0.00 & 0 & 0 & CL88-4730 & СР04-1252 & X10-0159 & 35 & 0.31 & 17.1 & 1.83 & СР06-2400 & Poly10-04 \\
\hline X09-1236 & 44 & 0.00 & 0 & 0 & СР03-1160 & СР04-1105 & X09-1235 & 32 & 0.31 & 15.6 & 2.00 & СР01-2390 & СР04-1105 \\
\hline X09-1110 & 84 & 0.00 & 0 & 0 & CL95-5255 & Mix09E & X10-0476 & 24 & 0.29 & 20.8 & 1.40 & СР06-2664 & CPCL06-3332 \\
\hline X09-1091 & 24 & 0.00 & 0 & 0 & СР78-1628 & СР80-1743 & X10-0812 & 24 & 0.29 & 16.7 & 1.75 & CPCL02-7386 & СР06-2170 \\
\hline X09-1087 & 21 & 0.00 & 0 & 0 & CL88-4730 & СР80-1743 & X10-0286 & 30 & 0.28 & 13.3 & 2.13 & CPCL02-8021 & L01-283 \\
\hline X09-1050 & 24 & 0.00 & 0 & 0 & СР97-1777 & CL92-1787 & X09-0972 & 209 & 0.28 & 18.2 & 1.51 & СР06-2214 & Poly09-25 \\
\hline X09-0888 & 26 & 0.00 & 0 & 0 & СР06-2664 & Poly09-24 & X11-0405 & 31 & 0.27 & 16.1 & 1.70 & СР92-1167 & СР06-2897 \\
\hline X09-0887 & 26 & 0.00 & 0 & 0 & СР06-2657 & Poly09-24 & X09-0884 & 37 & 0.27 & 18.9 & 1.43 & CPCL01-0271 & Poly09-24 \\
\hline X09-0874 & 33 & 0.00 & 0 & 0 & CPCL05-1108 & Poly09-23 & X09-0995 & 119 & 0.27 & 14.3 & 1.88 & СР92-1167 & Poly09-26 \\
\hline X09-0867 & 20 & 0.00 & 0 & 0 & СР02-2281 & Poly09-23 & X10-0816 & 21 & 0.26 & 19.0 & 1.38 & CPCL01-6755 & СР06-2170 \\
\hline X09-0458 & 45 & 0.00 & 0 & 0 & CPCL02-8021 & Poly09-14 & X10-0206 & 38 & 0.25 & 15.8 & 1.58 & СР05-1451 & Mix10-01 \\
\hline X09-0457 & 23 & 0.00 & 0 & 0 & CPCL02-7363 & Poly09-14 & X10-0165 & 74 & 0.23 & 14.9 & 1.55 & СР03-1026 & Poly10-04 \\
\hline X09-0447 & 21 & 0.00 & 0 & 0 & СР01-2459 & Poly09-14 & X10-0213 & 49 & 0.22 & 14.3 & 1.57 & СР08-1032 & СР06-2897 \\
\hline X09-0388 & 44 & 0.00 & 0 & 0 & СР06-2335 & Poly09-13 & X11-0498 & 28 & 0.20 & 14.3 & 1.38 & СР92-1167 & ТСР04-4709 \\
\hline X09-0186 & 21 & 0.00 & 0 & 0 & СР96-1252 & ТСР98-4447 & X09-0784 & 17 & 0.18 & 11.8 & 1.50 & СР96-1252 & Poly09-21 \\
\hline X09-0178 & 26 & 0.00 & 0 & 0 & СР04-1844 & СР04-1844 & X10-0445 & 20 & 0.18 & 14.3 & 1.17 & СР05-1451 & СР02-2281 \\
\hline X07-1299 & 24 & 0.00 & 0 & 0 & СР00-1751 & Mix07S & X10-0833 & 24 & 0.17 & 16.7 & 1.00 & CPCL01-0271 & Poly10-16 \\
\hline X07-1284 & 60 & 0.00 & 0 & 0 & СР92-1167 & Poly07-16 & X11-0497 & 16 & 0.13 & 12.5 & 1.00 & СР97-1777 & ТСР04-4709 \\
\hline X07-0869 & 56 & 0.00 & 0 & 0 & CPCL05-1102 & Poly07-07 & X10-0116 & 19 & 0.11 & 5.3 & 2.00 & СР06-2400 & СР04-1844 \\
\hline Mean $\dagger$ & $33(42)$ & $0.00(0.39)$ & $0.0(35.8)$ & $0.00(2.0)$ & & & Mean & $46(43)$ & $0.24(0.97)$ & $15.5(51.6)$ & $1.56(1.85)$ & & \\
\hline Max & $84(214)$ & $0.00(2.23)$ & $0.0(82.1)$ & $0.00(3.0)$ & & & $\operatorname{Max}$ & $209(209)$ & $0.32(2.11)$ & $20.8(100)$ & $2.13(2.44)$ & & \\
\hline Min & $20(15)$ & $0.00(0.00)$ & $0.0(2.3)$ & $0.00(1.4)$ & & & Min & $16(15)$ & $0.11(0.11)$ & $5.3(5.3)$ & $1.00(1.00)$ & & \\
\hline $\mathrm{CV}(\mathrm{A}) \stackrel{+}{\dagger}$ & $51.5(71)$ & --- (94.1) & --- (44.5) & --- (10.5) & & & $\mathrm{CV}(\mathrm{A})$ & $100(66)$ & $27.8(46.9)$ & $22.4(39.4)$ & $19.9(13.5)$ & & \\
\hline $\mathrm{CV}(\mathrm{W})$ & & $---(255)$ & & --- (13.8) & & & $\mathrm{CV}(\mathrm{W})$ & & 255.1 (118.6) & $28.9(27.3)$ & & & \\
\hline
\end{tabular}

The first values of mean, Maximum (Max), Minimum (Min) and CV are calculated based on the lowest 20 families and the second values within parentheses are based on all 279 (2012) or 265 (2013) families with $\geq 15$ clones planted

${ }^{*}$ The CV (A) and CV (W) represent among- and within-family CVs, respectively 


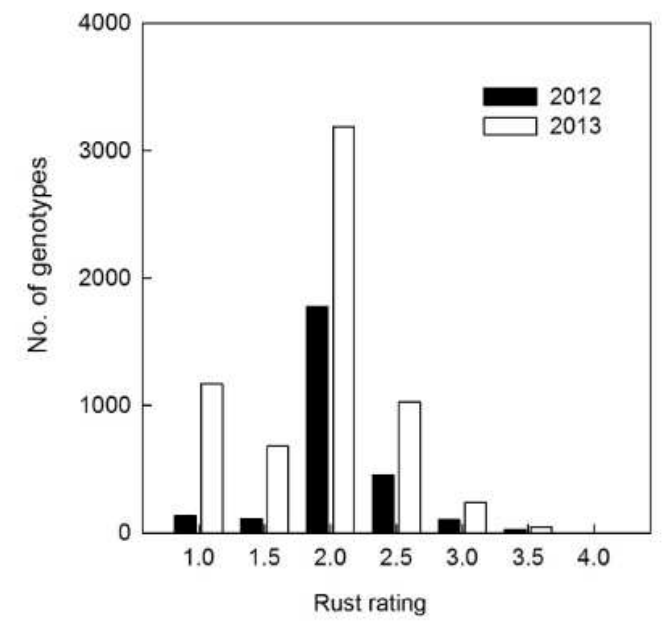

\begin{tabular}{lcc}
\hline Variable & $\mathbf{2 0 1 2}$ & $\mathbf{2 0 1 3}$ \\
\hline Total clones planted & 14,272 & 12,661 \\
No. of clones infected & 2,607 & 6,356 \\
\% of infection & 18.3 & 50.2 \\
Severity (mean rating of infected clones) & 2.07 & 1.89 \\
Overall mean rating (including no-infected clones) & 0.36 & 0.95 \\
\hline
\end{tabular}

Fig. 1. Distributions of orange rust on the number of the infected clones at different rust rating levels from 1 to 4 in Stage I of the Canal Point (CP) sugarcane development program in 2012 and 2013. Note: Rust ratings were assessed in July; the rust rating is equal to 0 or no rust infected clones and other important parameters are also listed in the inserted table of the figure
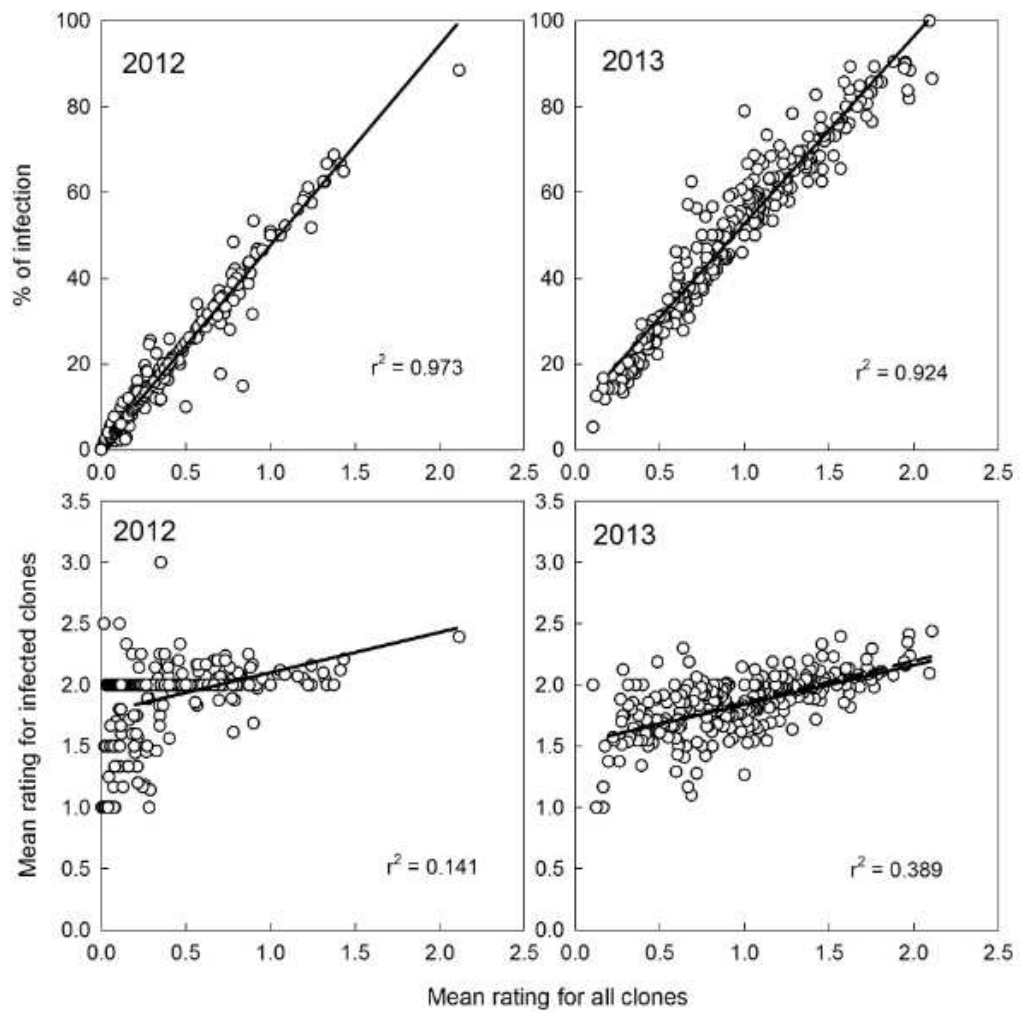

Fig. 2. Relationships between mean rust ratings and \% infection or severity (calculated by mean rating of infected clones) of orange rusts for 295 and 263 families with $\geq 15$ clones, respectively, in the 2012 and 2013 Stage I of the Canal Point (CP) sugarcane breeding and cultivar development program 
Table 5. Number of total sugarcane clones planted and mean Orange Rust (OR) rating for the 20 females with the highest mean OR ratings using 135 and 113 females with $\geq 15$ progeny clones in Stage I of the Canal Point (CP) sugarcane cultivar development program in 2012 and 2013, respectively

\begin{tabular}{|c|c|c|c|c|c|}
\hline \multicolumn{3}{|l|}{2012} & \multicolumn{3}{|l|}{2013} \\
\hline Female & No. clone & Mean OR rating & Female & No. clone & Mean OR rating \\
\hline CP00-1101 & 26 & 2.23 & CL94-0150 & 43 & 1.97 \\
\hline СР94-2203 & 146 & 1.31 & CL87-2282 & 20 & 1.95 \\
\hline СР02-1554 & 23 & 1.22 & CL87-1630 & 61 & 1.83 \\
\hline СР04-1250 & 135 & 1.17 & CPCL96-4974 & 28 & 1.77 \\
\hline CL87-1630 & 150 & 1.12 & СР97-1387 & 18 & 1.75 \\
\hline CL87-2882 & 83 & 1.12 & СР88-1762 & 96 & 1.69 \\
\hline НоСР04-856 & 16 & 1.09 & CPCL02-6334 & 33 & 1.68 \\
\hline CP88-1762 & 44 & 1.08 & CP57-0614 & 28 & 1.63 \\
\hline СР05-1518 & 56 & 1.04 & СР08-2003 & 25 & 1.62 \\
\hline СР99-1896 & 178 & 1.03 & CPCL99-2574 & 28 & 1.59 \\
\hline СР02-1143 & 54 & 1.02 & СР94-2203 & 404 & 1.58 \\
\hline CP84-1198 & 17 & 1.00 & СР00-2188 & 37 & 1.55 \\
\hline CPCL99-2103 & 65 & 0.95 & СР06-2897 & 51 & 1.49 \\
\hline CPCL05-1009 & 18 & 0.92 & CPCL99-2103 & 36 & 1.49 \\
\hline CP80-1743 & 20 & 0.90 & CP99-1896 & 48 & 1.48 \\
\hline L07-057 & 17 & 0.88 & CL90-4643 & 58 & 1.42 \\
\hline CPCL02-8017 & 33 & 0.86 & CP01-2365 & 128 & 1.42 \\
\hline CPCL00-4027 & 30 & 0.85 & СР05-1730 & 92 & 1.41 \\
\hline СР06-2874 & 28 & 0.84 & СР04-1250 & 162 & 1.40 \\
\hline СР00-2188 & 65 & 0.84 & CPCL02-6848 & 19 & 1.39 \\
\hline Mean $^{\dagger}$ & $60(102)$ & $1.07(0.44)$ & Mean $^{\dagger}$ & $71(108)$ & $1.60(1.02)$ \\
\hline Max & $178(639)$ & $2.23(2.23)$ & Max & $404(630)$ & 1.97 (1.97) \\
\hline Min & $16(15)$ & $0.84(0.00)$ & Min & $18(16)$ & $1.39(0.22)$ \\
\hline $\mathrm{CV}(\mathrm{A})^{\ddagger}$ & $85.3(108.7)$ & $28.3(78.0)$ & CV(A) & $123.5(109.3)$ & $11.1(39.0)$ \\
\hline $\mathrm{CV}(\mathrm{W})$ & & $109.8(262.9)$ & $\mathrm{CV}(\mathrm{W})$ & & $60.0(108.7)$ \\
\hline
\end{tabular}

${ }^{\dagger}$ The first values of mean, Maximum (Max), Minimum (Min) and CV are calculated based on the top 20 female parents based on the mean rating of orange rust and the second values within parentheses are based on all 136 (2012) or 113 (2013) female parents with $\geq 15$ clones planted

${ }^{\ddagger}$ The CV (A) and CV (W) represent among- and within-family CVs, respectively

This substantial variability in the number of clones among families was probably associated with differences in the number of viable seeds per cross in the Crossing stage and/or low selection intensity in the Seedling stage for some families that had poor performance in seedling fields. On a family basis, mean rust ratings ranged from 0.0 to 2.5 in both years. Among-family CV values of orange rust were $104.9 \%$ in 2012 and $52.7 \%$ in 2013 . Within-family CVs were greater than their among-family CVs.

Large variability in the number of clones and in rust ratings (Table 2) among families in Stage I of the CP program suggested that Stage I data can be used to identify useful parental combinations and individual parents for their progenies to be resistant/tolerant to orange rust in the test years. The greater $\mathrm{CV}$ values for rust rating within families than among families suggested that placing more emphasis on both individual clonal evaluation and family-based evaluation in Stage I of the CP program may help improve our knowledge and ability to select genotypes with potential for eliminating rust effects.

\section{Correlations of Mean Rust Ratings with \% Infection and Severity}

In 576 (2012) and 455 (2013) families planted in Stage I, 295 and 263 families, respectively, had $\geq 15$ clones. From these families with $\geq 15$ clones, the mean ratings, $\%$ infections and severity values of orange rusts for each family were calculated (Fig. 2). Overall, the mean ratings of orange rust ranged from 0.0 to 2.1 ; the values of $\%$ infection ranged from 2.3 to $100.0 \%$ and the values of severity (i.e., mean ratings calculated based on infected clones) ranged from 1.0 to 3.0. Averaged across years, the $\mathrm{CV}$ values of the mean rating, \% infection and severity were $69.8,41.8$ and $11.8 \%$, respectively among these families. The mean ratings of orange rust highly correlated with $\%$ infection $\left(\mathrm{r}^{2}=0.92-0.97\right)$, but the relationships between the mean ratings and severity values were poor $\left(\mathrm{r}^{2}=0.14-0.39\right)$ (Fig. 2). Consideration of Variability (CV) and correlation between the three rust variables, the rust severity might not be a good parameter to distinguish family differences in response to orange rust in the early selection stage of sugarcane breeding program. 
Table 6. Number of total sugarcane clones planted and mean Orange Rust (OR) rating for the 20 females with the lowest mean OR ratings using 135 and 113 females with $\geq 15$ progeny clones in Stage I of the Canal Point (CP) sugarcane cultivar development program in 2012 and 2013, respectively

\begin{tabular}{|c|c|c|c|c|c|}
\hline \multicolumn{3}{|l|}{2012} & \multicolumn{3}{|l|}{2013} \\
\hline Female & No. clone & Mean OR rating & Female & No. clone & Mean OR rating \\
\hline СР02-1985 & 103 & 0.12 & CPCL08-2274 & 36 & 0.61 \\
\hline СР96-1252 & 192 & 0.11 & ТСР04-4688 & 18 & 0.61 \\
\hline CPCL97-0393 & 87 & 0.10 & СР08-1965 & 128 & 0.61 \\
\hline СР01-2459 & 88 & 0.10 & СР00-1301 & 28 & 0.61 \\
\hline СР06-2657 & 40 & 0.10 & CL88-4730 & 91 & 0.57 \\
\hline CPCL02-2273 & 39 & 0.09 & CPCL96-2061 & 24 & 0.54 \\
\hline СР00-2180 & 68 & 0.09 & СР05-1451 & 374 & 0.53 \\
\hline CL88-4730 & 332 & 0.08 & СР07-2301 & 17 & 0.53 \\
\hline CPCL02-8001 & 61 & 0.07 & СР01-2390 & 204 & 0.51 \\
\hline СР01-2390 & 259 & 0.06 & CPCL97-0393 & 38 & 0.46 \\
\hline СР00-2164 & 51 & 0.06 & СР96-1252 & 243 & 0.44 \\
\hline СР03-1160 & 72 & 0.06 & CPCL01-6755 & 190 & 0.42 \\
\hline CPCL02-7386 & 73 & 0.05 & СР03-1026 & 261 & 0.41 \\
\hline CPCL05-1201 & 106 & 0.04 & ТСР04-4685 & 26 & 0.38 \\
\hline CP92-1167 & 496 & 0.03 & СР08-2398 & 36 & 0.36 \\
\hline СР01-1178 & 38 & 0.03 & СР92-1167 & 285 & 0.34 \\
\hline CPCL00-1373 & 58 & 0.03 & СР06-2214 & 252 & 0.34 \\
\hline СР89-2143 & 115 & 0.02 & СР06-3098 & 16 & 0.25 \\
\hline СР00-1751 & 24 & 0.00 & СР08-1032 & 49 & 0.22 \\
\hline СР06-3098 & 20 & 0.00 & СР06-2400 & 63 & 0.22 \\
\hline Mean $^{\dagger}$ & $116(102)$ & $1.07(0.44)$ & Mean $^{\dagger}$ & $119(108)$ & $0.45(1.02)$ \\
\hline $\operatorname{Max}$ & $496(639)$ & $2.23(2.23)$ & $\operatorname{Max}$ & $374(630)$ & $0.61(1.97)$ \\
\hline Min & $20(15)$ & $0.84(0.00)$ & Min & $16(16)$ & $0.22(0.22)$ \\
\hline CV $(A)$ & $102.9(108.7)$ & $28.3(78.0)$ & CV(A) & $95.4(109.3)$ & $29.1(39.0)$ \\
\hline $\mathrm{CV}(\mathrm{W})$ & & $109.8(262.9)$ & $\mathrm{CV}(\mathrm{W})$ & & $182.7(108.7)$ \\
\hline
\end{tabular}

${ }^{\dagger}$ The first values of mean, Maximum (Max), Minimum (Min) and CV are calculated based on the lowest 20 female parents based on the mean rating of orange rust and the second values within parentheses are based on all 136 (2012) or 113 (2013) female parents with $\geq 15$ clones planted

\$The CV (A) and CV (W) represent among- and within-family CVs, respectively

\section{Evaluation of Families Based on Mean Rust Ratings}

The families with $\geq 15$ clones were also used to evaluate family tolerance to orange rust. The 295 and 263 families that had $\geq 15$ clones planted in Stage I in 2012 and 2013, respectively, were ranked based on their mean ratings of orange rust (Tables 3 and 4). The mean orange rust ratings across families were 0.4 (ranged from 0.0 to 2.2) in 2012 and 1.0 (ranged from 0.1 to 2.1) in 2013 with the CV values of 94 and $47 \%$, respectively. Top 20 families with the highest (Table 3) and 20 families with the lowest (Table 4) mean rust ratings in each year were identified. The \% infection and severity of orange rust for the families and their parents are also listed in Tables 3 and 4. Orange rust had greater variability $(\mathrm{CV})$ in the mean rating and in severity within the family than among families and the $\mathrm{CV}$ values of the mean orange rust rating were greater than those of orange rust severity. Parental information of these families might help breeders select proper parents for crossing to develop genotypes with resistance to orange rust. The results of orange rust suggest that using $\mathrm{CP}$ 942203, CP 04-1250 and CP 99-1896 as female parents will increase probability to produce progenies with high susceptibility to orange rust (Table 3 ). In contrast, using CP
06-2664, CP 92-1167 and CL 88-4730 as female parents may improve orange rust resistance of progeny (Table 4).

\section{Evaluation of Females Based on Mean Rust Ratings of Their Progenies}

When data were analyzed by female parents regardless of families and males, there were 204 and 157 females used for generating the Stage I clones, respectively, in 2012 and 2013. Of these females, 135 in 2012 and 113 in 2013 females had at least 15 progenies planted in the Stage I fields. The progenies of these females were sorted by the rust mean ratings. The 20 females with their progenies having the highest (Table 5) and 20 females with progenies having the lowest (Table 6) mean rating of orange rust were further identified and ranked.

Orange rust is one of the most devastated sugarcane diseases for sugarcane production in Florida. Using proper parents with resistance to orange rust to make crosses is the priority for the CP program. There was great variation in orange rust ratings among families (Tables 3 and 4) in Stage I of the CP program. The great variation in mean ratings of orange rust among female parents for their progenies was also detected (Tables 5 and 6). Clearly, using clones listed in Table 5 as female parents increased the risk to get progenies with high orange rust ratings. In both years, progenies from 
females CP 94-2203, CP 04-1250, CL 87-1630, CP 881762, CPCL 99-2103 and CP 00-2188 had high mean rating of orange rust and ranked in the top 20 (Table 5). These female parents should be limited in the CP program to develop genotypes with resistance to orange rust. Overall, the progenies developed from female parents listed in Table 6 had the lowest mean ratings of orange rust. Increase in proportion of these female clones for crossing might improve resistance to orange rust of progenies in Stage I of the CP program.

\section{Discussion}

Sugarcane orange rust is a devastating disease for sugarcane production in the United States because most commercial cultivars are susceptible to this disease and it caused substantial yield loss of susceptible varieties (Raid et al., 2013). Multiple approaches have been and are being used for eliminating rust negative effect on yield of sugarcane. These include disease monitoring, adjustment of management practices, fungicide applications (Raid et al., 2011) and development of new cultivars with resistance to orange rust by intensive screening in the breeding program (Zhao et al., 2013). The increase in frequent applications of fungicides results in high input cost and low net profits of sugarcane production (Jiang, 1985; Staier et al., 2003). Therefore, development of rust resistant varieties is important for sustaining sugarcane production and for improving production and profitability.

In the present study, we investigated orange rust disease in the first colonal stage of the CP program based on three parameters of mean rust rating, percentage of infection and severity and found that great variability (CV) existed in both mean rust ratings and \% infection across large numbers of clones and families. Therefore, these two parameters can be used to evaluate genotypes for orange rust resistance. The rust severity might not a good parameter to distinguish family differences in response to orange rust in the early selection stage of sugarcane breeding program because of relatively smaller CVs than the mean rust rating or \% infection.

It is important for sugarcane breeders to develop a data base of parental clones using agronomic and physiological traits and molecular markers for disease resistance and for yield and profit improvement. Virtudazo et al. (2001) conducted phylogenetic analysis of sugarcane rusts, including orange rust, based on rDNA sequences. Sugarcane brown rust resistance gene (Bru1) has been used as a marker to identify if sugarcane genotypes are potentially resistant to brown rust (Asnaghi et al., 2004). This technology was also utilized in the $\mathrm{CP}$ program to direct breeding strategies for brown rust resistance (Glynn et al., 2013). Scientists are working on developing a reference genomic map and identifying the markers linked to sugarcane orange rust resistance genes (Yang et al., 2014). However, the molecular markers for orange rust resistance are not commercially available yet. Traditional breeding approaches for rust resistance have involved a better understanding of inheritance of resistance in seedling populations (Ramdoyal et al., 2000) and selection and advancement of genotypes that are free from visual disease symptoms. To evaluate performance of sugarcane families in some specific traits, Wang et al. (2008) suggested that at least 10 to 20 clones per family were required. Therefore, the families that had $\geq 15$ clones and females that had $\geq 15$ progeny clones were used in the present study to assess orange rust resistance at the family and female parental levels based on the disease data collected from individual clones. Our results indicated that orange rust ratings collected in the first clonal stage can be used not only for advancing elite clones to next stage of the CP program as one of selecting criteria, but also for evaluating families and their parents for orange rust resistance. These findings could be useful for breeders to design cross combinations and to improve selection efficiency of new cultivars for rust resistance.

Shanthi et al. (2008) suggested that parents producing progeny with a high frequency of transgressive recombination for agronomic traits should provide the best opportunity for sugarcane breeders to select clones superior to their parents. In addition to directly evaluating parental lines for disease resistant traits, therefore, parental evaluation based on their progeny performance for rust resistance and other agronomic traits in the early clonal stage of a sugarcane breeding program with large numbers of clones might help optimize parental selection and crossing combination. Quantitative analyses of sugarcane clonal data of rusts in Stage I of the CP program could help us evaluate not only crosses (families), but also their parents as described above. Studies have suggested that family selection is effective in improving sugarcane populations in early selection stages (Chang and Milligan, 1992; Cox and Hogarth, 1993; McRae et al., 1993; Shanthi et al., 2008) because it can identify those families that harbor the highest proportion of desirable clones and makes it possible to focus selection for superior clones (Shanthi et al., 2008). Availability of family data in rust diseases helps sugarcane breeders improve crossing combinations for developing genotypes with resistance to diseases and high yields.

\section{Conclusion}

Early stage selection methods and specific selection strategies of sugarcane cultivar development programs are dependent on environmental conditions and the unique goals of each selection program. Analyses of orange rust data collected from large numbers of individual clones in Stage I of the CP program in 2012 
and 2013 revealed that there was great variation in orange rust ratings among genotypes and among families. Our results indicated that using the rust rating data along with individual selection data on plant vigor and stalk juice Brix (Zhao et al., 2012) for making comparisons of family performance and among- and within-family variability would improve our parental selection and optimize crosses among selected parents, which should then improve the progenies for rust resistance and yield potential in the sugarcane breeding programs.

\section{Acknowledgment}

The authors thank Philip Aria for his valuable technical assistance and skilled data management. We also appreciate Tom Abbott and all other staff at the USDA-ARS Sugarcane Field Station for help on planting, field management and harvest.

\section{Funding Information}

This article was funded in part by the Florida Sugar Cane League, Inc.

\section{Author's Contributions}

Duli Zhao: Contributed to conception and design of the experiment, analyzed and interpreted data, wrote the manuscript and integrated all ideas and comments from other authors and peer reviewers.

R. Wayne Davidson: Coordinated the work of data acquisition, analysis and interpretation.

Miguel Baltazar: Coordinated the work of data acquisition and analysis.

Jack C. Comstock: Made contributions to the original ideas of the experiment and disease data quality.

\section{Ethics}

The authors wish to state that this article conforms to the ethical standards specified by the American Journal of Agricultural and Biological Sciences.

\section{References}

Asnaghi, C., D. Roques, S. Ruffel, C. Kaye and J.Y. Hoarau et al., 2004. Targeted mapping of a sugarcane rust resistance gene (Bru1) using bulked segregant analysis and AFLP markers. Theor. Appl. Genet., 108: 759-764.

DOI: $10.1007 / \mathrm{s} 00122-003-1487-6$

Barbasso, D., H. Jordão, W. Maccheroni, J. Boldini and J. Bressiani et al., 2010. First report of Puccinia kuehnii, causal agent of orange rust of sugarcane, in Brazil. Plant Dis., 94: 1170. DOI: 10.1094/PDIS-94-9-1170C
Braithwaite, K.S., B.J. Croft, R.C. Magarey and T. Scharaschkin, 2009. Phylogenetic placement of the sugarcane orange rust pathogen Puccinia kuehnii in a historical and regional context. Aust. Plant Pathol., 38: 380-388. DOI: 10.1071/AP09012

Chavarría, E., F. Sabiros, J. Vega, G. Ralda and N.C. Glynn et al., 2009. First report of orange rust of sugarcane caused by Puccinia kuehnii in Costa Rica and Nicaragua. Plant Dis., 93: 425. DOI: 10.1094/PDIS-93-4-0425C

Chang, Y.S. and S.B. Milligan, 1992. Estimating the potential of sugarcane families to produce elite genotypes using univariate cross prediction methods. Theor. Appl. Genet., 84: 662-671.

Cox, M.C. and D.M. Hogarth, 1993. The Effectiveness of Family Selection in Early Stages of Sugarcane Improvement Program. In: Focused Plant Improvement: Towards Responsible and Sustainable Agriculture: Tenth Australian Plant Breeding Conference, B.C. Imrie and J.B. Hacker, (Eds.). Catalogue, pp: 53-54.

Comstock, J.C., S.G. Sood, N.C. Glynn, J.M. Shine, Jr. and J.M. McKemy et al., 2008. First report of Puccinia kuehnii, causal agent of orange rust of sugarcane, in the United States and in the Western Hemisphere. Plant Dis., 92: 175. DOI: 10.1094/PDIS-92-1-0175A

Edme, S.J., J.D. Miller, B. Glaz, P.Y.P. Tai and J.C. Comstock, 2005. Genetic contribution to yield gains in the Florida sugarcane industry across 33 years. Crop Sci., 45: 92-97. DOI: $10.2135 /$ cropsci2005.0092

Edme, S.J., P.Y.P. Tai, B. Glaz, R.A. Gilbert and J.D. Miller et al., 2005. Registration of 'CP 96-1252' sugarcane. Crop Sci., 45: 423.

Flores, R.C., J.R. Loyo, R.A. Ojeda, O.C.A. Rangel and F.A. Cerón et al., 2009. First report of orange rust of sugarcane caused by Puccinia kuehnii in Mexico, El Salvador and Panama. Plant Dis., 93: 1347. DOI: 10.1094/PDIS-93-12-1347B

Gilbert, R.A., J.C. Comstock, B. Glaz, S.J. Edme and R.W. Davidson et al., 2008. Registration of 'CP 001101' sugarcane. J. Plant Reg., 2: 95-101. DOI: $10.3198 /$ jpr2007.12.0660crc

Glaz, B., J.D. Miller, C.W. Deren, P.Y.P. Tai and J.M. Shine Jr. and J.C. Comstock. 2000. Registration of 'CP 89-2143' sugarcane. Crop Sci. 40: 577. DOI: $10.2135 /$ cropsci2000.0025rcv

Glynn, N.C., C. Laborde, R.W. Davidson, M.S. Irey and B. Glaz et al., 2013. Utilization of a major brown rust resistance gene in sugarcane breeding. Mol. Breeding, 31: 323-331. DOI: $10.1007 / \mathrm{s} 11032-012-9792-\mathrm{x}$

Grisham, M.P., J.W. Hoy, J.S. Haudenshield and G.L. Hartman. 2013. First report of orange rust caused by Puccinia kuehnii in Sugarcane in Louisiana. Plant Dis., 97: 426.

DOI: 10.1094/PDIS-09-12-0873-PDN 
Jiang, D.K., 1985. Chemical control of sugarcane rust $P$. melanocephala. Rep. Taiwan Sugar Res. Inst., 108: 25-34.

Machado, G.R. Jr., 2013. The spread of CP varieties, Canal Point, Florida, USA in other countries. Sugar J., 77: 20-21.

McRae, T.A., D.M. Hogarth, J.F. Foreman and M. Braithwaite, 1993. Selection sugarcane families in the Burdekin district. In: Focused Plant Improvement: Towards Responsible and Sustainable Agriculture, B.C. Imrie and J.B. Hacker (Eds.). pp: $77-82$.

Ovalle, W., J.C. Comstock, N.C. Glynn and L.A. Castlebury, 2008. First report of Puccinia kuehnii, causal agent of orange rust of sugarcane, in Guatemala. Plant Dis., 92: 973.

DOI: 10.1094/PDIS-92-6-0973C

Raid, R.N., J.C. Comstock and S. Sood, 2013. Sugarcane orange rust in Florida: Its history, current status and management. J. Am. Soc. Sugar Cane Technol., 33: 57.

Raid, R.N., J.M. Shine, J. Mitchell and N. Glynn, 2011. Yield response by rust susceptible cultivars to foliar fungicide applications applied to commercial sugarcane fields. J. Am. Soc. Sugar Cane Technol., 32: 65-66.

Ramdoyal, K., S. Sullivan, L.C.Y. Lim Shin Chong, G.H. Badaloo and S. Saumtally et al., 2000. The genetics of rust resistance in sugar cane seedling populations. Theor. Appl. Genet., 100: 557-563. DOI: $10.1007 / \mathrm{s} 001220050073$

Rice, R., L. Baucum and B. Glaz, 2013. Sugarcane variety census: Florida 2012. Sugar J., 76: 11-19.

Shanthi, R.M., K.V. Bhagyalakshmi, G. Hemaprabha, S. Alarmelu and R. Nagarajan, 2008. Relative performance of the sugarcane families in early selection stages. Sugar Tech., 10: 114-118. DOI: $10.1007 / \mathrm{s} 12355-008-0019-8$

Sood, S.G., J.C. Comstock and N.C. Glynn, 2009. Leaf whorl inoculation method for screening sugarcane rust resistance. Plant Dis., 93: 1335-1340.

DOI: 10.1094/PDIS-93-12-1335

Staier, T., R. Magarey and T.G. Willcox, 2003. Control of orange rust in sugarcane with fungicides. Proc. Aust. Soc. Sugar Cane Technol.

Tai, P.Y.P. and J.D. Miller, 1989. Family performance at early stages of selection and frequency of superior clones from crosses among Canal Point cultivars of sugarcane. J. Am. Soc. Sugar Cane Technol., 9: 62-70.

Tai, P.Y.P., J.D. Miller, B. Glaz, C.W. Deren and J.M. Shine, 1991. Registration of 'CP 78-1628' sugarcane. Crop Sci., 31: 236.

DOI: $10.2135 /$ cropsci1991.0011183X003100010067x
Tai, P.Y.P., J.M. Shine Jr., C.W. Deren, B. Glaz, J.D. Miller and J.C. Comstock, 1997. Registration of ' $\mathrm{CP}$ 88-1762' sugarcane. Crop Sci., 37: 1388. DOI: 10.2135/cropsci1997.0011183X003700040074x

USDA-NASS, 2014. Crop values 2013 summary (February 2014) crop. Department of Agriculture, USA.

Virtudazo, E.V., H. Nakamura and M. Kakishima, 2001. Phylogenetic analysis of sugarcane rusts based on sequences of ITS, 5.8 S rDNA and D1/D2 regions of LSU rDNA. J. Gen. Plant Pathol., 67: 28-36. DOI: 10.1007/PL00012983

Wang, L.P., P.A. Jackson, X. Lu, Y.H. Fan and J.W. Foreman et al., 2008. Evaluation of sugarcane $\times$ Saccharum spontaneum progeny for biomass composition and yield components. Crop Sci., 48: 951-961. DOI: 10.2135/cropsci2007.10.0555

Yang, X., N. Glynn, J. Comstock and J. Wang, 2014. Developing a reference genomic map and identifying the markers linked to sugarcane orange rust resistance genes. Int. Plant \& Animal Genome XXII Conf., P88.

Zhao, D., J.C. Comstock, B. Glaz, S.J. Edmé and R.W. Davidson et al., 2013. Registration of 'CP 05-1526' sugarcane. J. Plant Reg., 7: 305-311. DOI: $10.3198 / j p r 2013.02 .0007 \mathrm{crc}$

Zhao, D., J.C. Comstock, B. Glaz, S.J. Edmé and N.C. Glynn et al., 2012. Vigor rating and Brix for first clonal selection stage of the Canal Point sugarcane cultivar development program. J. Crop Improv., 26: 60-75. DOI: 10.1080/15427528.2011.611926

Zhao, D., B. Glaz and J.C. Comstock. 2010. Sugarcane response to water deficit stress during early growth on organic and sand soils. Am. J. Agric. Biol. Sci. 5: 403-414. DOI: 10.3844/ajabssp.2010.403.414

Zhao, D., N.C. Glynn, B. Glaz, J.C. Comstock and S. Sood. 2011. Orange rust effects on leaf photosynthesis and related characters of sugarcane. Plant Dis. 95: 640-647.

DOI: 10.1094/PDIS-10-10-0762 